\author{
Eugeniusz CikaŁo, Stefan NowosiadŁo
}

Uniwersytet Lwowski im. I. Franka

\title{
Stworzenie specjalnych stref ekonomicznych - poważny czynnik restrukturyzacji gospodarki
}

Głównym celem dzisiejszej polityki regionalnej Ukrainy jest stworzenie prawnych i ekonomicznych warunków dla efektywnego wykorzystania potencjału zasobów każdego regionu, jego umiejscowienia geopolitycznego w oparciu o przeszłość historyczno-kulturową. Jednym $z$ efektywnych mechanizmów terytorialno-gospodarczej organizacji gospodarki, jej restrukturyzacji, rozszerzenia samodzielności regionów jest sformowanie specjalnych stref ekonomicznych (SSE), na terenach których wprowadza się ulgi celne, waluto-

wo-finansowe, podatkowe oraz inne warunki sprzyjające rozwojowi działalności krajowych i zagranicznych osób prawnych i fizycznych.

Celem stworzenia SSE jest:

- stymulowanie przekształceń strukturalnych w gospodarce poprzez przyciąganie inwestycji zagranicznych;

- aktywizacja wspólnie z inwestorami zagranicznymi działalności przedsiębiorczej dla zwiększenia eksportu towarów i usług;

- zwiększenie dostarczania na rynek wewnętrzny wysokogatunkowej produkcji i usług;

- aktywizacja wymiany naukowo-technicznej i wprowadzenie nowych technologii;

- wprowadzenie doświadczeń organizacyjnych i metod kierowania gospodarką rynkową;

- stworzenie nowoczesnej infrastruktury rynkowej;

- ulepszenie wykorzystania zasobów naturalnych i pracowniczych;

- przyspieszenie rozwoju społeczno-gospodarczego poszczególnych regionów i państwa oraz wzrost stopy życiowej ludności.

Mając na uwadze dzisiejszą sytuację ekonomiczną i konieczność wykorzystania obecnego potencjału produkcyjnego oraz kwalifikowanych środków produkcyjnych na Ukrainie sens będzie miało stworzenie szerokiej sieci SSE rozmaitych typów - z przewagą handlowych, kompleksowo-produkcyjnych, naukowo-technicznych, turystyczno-rekreacyjnych $\mathrm{i}$ in. Wybór sposobu organizacji SSE wynika z dwóch głównych kryteriów, tj. efektowności gospodarczej oraz optymalnych powiązań elementów typowych $\mathrm{z}$ warunkami specyficznymi danego obszaru i elementów gospodarczych. Zakłada się, że maksymalne efekty 
działalności SSE - przy minimalnych nakładach wstępnych - uzyskane zostaną przy stworzeniu stref różnej specjalizacji (eksportowych, importowych, tranzytowych).

W SSE towary pochodzenia zagranicznego mogą być chronione, kupowane i sprzedawane bez cła i celnych poborów, co sprzyja aktywizacji handlu zewnętrznego. Kryteria stworzenia stref takiego kształtu całkowicie realizują się w regionach przygranicznych, które już mają rozwiniętą infrastrukturę dla obsługi zewnętrznych potoków towarowych. Przyszłościowym i gospodarczo wartościowym kierunkiem jest stworzenie wielu wyprofilowanych stref zespołowych. W tych strefach wprowadza się specjalne ulgi podatkowe, dewizowo-finansowe, celne, które miałyby na celu stymulowanie przedsiębiorczości, podłączenie inwestycji w branże priorytetowe, rozwój międzynarodowych powiązań gospodarczych, wykorzystanie nowoczesnych technologii, zatrudnienie ludności. Mogą mieć one charakter eksportowych stref produkcyjnych, gdzie w pierwszej kolejności rozwija się produkcja

eksportowa, zorientowana na przetwórstwo własnych surowców i przeważnie montaż wyrobów importowanych. Do stworzenia eksportowo-wytwórczych stref z orientacją na wytwarzanie produkcji skomplikowanych maszyn, mebli, produkcji przemysłu lekkiego dobre warunki mają szczególnie zachodnie województwa Ukrainy (lwowskie, zakarpackie, czernowickie oraz Krym). Duże nadzieje pokłada się w stworzeniu stref naukowotechnicznych. Specjalne akty prawne orientuje się na rozwój działalności naukowej i potencjału produkcyjnego, osiaganie nowego rodzaju gospodarki przez stymulowanie podstawowych i aplikacyjnych badań naukowych, a następnie wprowadzenie tych opracowań naukowych do przedsiębiorstw. Najpoważniejsze możliwości rozwoju dzięki zasobom potencjału intelektualnego, naukowego oraz przedsiębiorczości mają takie miasta, jak Kijów, Charków, Lwów i Odesa.

$\mathrm{Na}$ Ukrainie powinno się też zmierzać do stworzenia ośrodków naukowotechnicznych różnej specjalizacji a także zaplecza technicznego i inkubatorów przedsiębiorczości, które będą sprzyjać dalszemu rozwojowi potencjału naukowo-technicznego i wdrażania innowacji w strefie produkcyjnej.

Również unikalny potencjał zasobów przyrodniczych Ukrainy, istniejące ośrodki lecznicze i wypoczynkowe, powiązane komunikacyjnie, a także znaczny popyt na usługi rekreacyjne stanowią potencjalne warunki dla stworzenia i funkcjonowania stref turystyczno-rekreacyjnych. W takich strefach istnieją podstawy dla aktywizacji działalności gospodarczej ( $\mathrm{w}$ tym z udziałem kapitałów zagranicznych) w sferę biznesu rekreacyjnoturystycz-nego. Podstawą dla stworzenia takich stref są regiony Karpat (województwa: lwowskie, zakarpackie, iwano-frankowskie) oraz województwo odeskie i Krym.

$\mathrm{W}$ celu zapewnienia normalnych warunków funkcjonowania stref oraz pobudzania mechanizmów inwestowania na takich terenach ustala się tryb specjalny dla przyciagnięcia inwestycji zagranicznych. Dlatego firmy zagraniczne otrzymują możliwość inwestowania określonych kwot $\mathrm{w}$ różne sektory, zgodnie $\mathrm{z}$ obowiązującym prawem Ukrainy o działalności gospodarczej (w tym strefy bankowej, ubezpieczeniowej), drogą:

- udziału majątkowego w przedsiębiorstwach, stwarzanych wspólnie z ukraińskimi osobami prawnymi i fizycznymi;

- stworzenia przedsiębiorstw zagranicznych, całkowicie należących do inwestorów zagranicznych oraz filii firm zagranicznych; 
- nabywania udziałów w istniejących przedsiębiorstwach, papierów wartościowych, prawa użytkowania gruntów i innych praw własnościowych;

- udzielania kredytów na inną działalność w ramach czynnego układu prawnego Ukrainy.

Problemy związane $\mathrm{z}$ finansowaniem i zabezpieczeniem infrastrukturowym w SSE mogą być częściowo rozwiązane drogą nadania oddzielnych terenów niezabudowanych w dzierżawę długoterminową na warunkach ulgowych z gwarancją prawną stabilności, pod warunkiem podjęcia określonych kierunków działalności gospodarczej.

Zgodnie z ustawą „O ogólnych zasadach stworzenia i funkcjonowania specjalnych stref ekonomicznych" państwo gwarantuje podmiotom gospodarczym działającym w SSE prawo do wywożenia zysków i kapitału inwestowanego w strefie za granicę Ukrainy. W SSE działają punkty konwencji Międzynarodowej Organizacji Pracy, a przedsiębiorstwa działające w SSE powinny przestrzegać zasad Deklaracji Międzynarodowej Organizacji Pracy

o ponadnarodowych przedsiębiorstwach i polityki socjalnej. Pracownikom zagranicznym gwarantowany jest przelew za granicę ich dochodów z pracy w SSE oraz nagromadzenia i odsetki od nich w finansowo-kredytowych zakładach SSE. Obywatele zagraniczni, jak i obywatele ukraińscy, którzy pracują w SSE, mogą przelewać swoje środki w jakikolwiek (nie zakazany prawem Ukrainy) rodzaj działalności gospodarczej, tak na obszarze SSE, jak i poza nim na terenie Ukrainy.

Rozbudowa SSE przewiduje:

- w celu opracowania mechanizmów organizacyjnych, finansowych i protekcyjnych stworzenie lokalnych albo tak zwanych punktowych SSE, zajmujących niewielkie terytorium;

- na podstawie punktowych SSE i odrębnych regionów stworzenie wielofunkcjonalnych SSE, a razem z terytorium innych państw - SSE międzynarodowych.

Duże zainteresowanie z punktu widzenia perspektywy współpracy międzynarodowej wywołują prace projektowe stworzenia punktowych SSE w przygranicznych obszarach województwa lwowskiego, szczególnie w powiecie jaworowskim. Powiat jaworowski znajduje się w północno-zachodniej części województwa lwowskiego i graniczy na zachodzie z Polską, na północnym wschodzie z powiatem żółkiewskim, na południu z powiatem mostyskim i gorodockim, a na wschodzie z miastem Lwów. Ogólny obszar powiatu wynosi 154,3 tys. ha, co stanowi 7,1\% obszaru województwa lwowskiego. W powiecie znajduje się 146 jednostek osadniczych, w tym 2 miasta (Jaworiw i Nowojaworiwsk), 4 osiedla typu miejskiego (Iwano-Frankowe, Krakiwiec, Nemyrów, Szkło), w których zamieszkuje 123,6 tys. osób. Jaworów jest oddalony od Lwowa o $54 \mathrm{~km} \mathrm{i} \mathrm{ma} \mathrm{z} \mathrm{nim} \mathrm{oraz} \mathrm{z} \mathrm{powiatami} \mathrm{sąsied-}$ nimi dobre połączenia samochodowe i kolejowe. Jest to powiat przemysłowo-rolniczy. W przemyśle zatrudnionych jest 9,5 tys. pracowników, w rolnictwie -7 tys., w sferze prywatnej - 2,5 tys.

Sytuacja społeczno-polityczna na Ukrainie cechuje się zaostrzeniem problemów o charakterze produkcyjnym i ekologicznym. Ze względu na ograniczone środki restrukturyzacja gospodarki i intensyfikacja przemysłu w regionie kosztem budżetu państwa jest niemożliwa. Dlatego samorząd lokalny razem z zakładami pracy i przy poparciu władz państwowych poszukują sposobów wyjścia z tej sytuacji. 
Położenie geograficzne powiatu stwarza warunki dla współpracy z państwami wschodniej i zachodniej Europy. W przyszłości przez teren powiatu przebiegać będzie droga międzynarodowa Berlin-Wrocław-Kraków-Lwów-Kijów, która będzie połączona z transeuropejską magistralą Lizbona-Triest-Budapeszt-Kijów. Zbudowanie takiej trasy pozwoli znacznie skrócić drogę z państw Europy Zachodniej do portów Morza Bałtyckiego i Morza Czarnego (Gdańsk-Odesa) i odwrotnie. Otwarcie w tej strefie - na granicy z Polską - jednego z największych przejść granicznych dla samochodów (5000 samochodów na dobę) poważnie skróci czas przekraczania granicy i oczywiście podwyższy jakość usług. Przy magistrali planuje się stworzenie specjalnej strefy ekonomicznej (SSE „Jaworiw”), co przekształci ten region w atrakcyjny obszar dla inwestorów zagranicznych. Obecnie przygotowane zostało zaplecze techniczno-ekonomiczne oraz zatwierdzony został niezbędny akt prawny. SSE będzie mieć status terytorium z określonym planem zagospodarowania, zgodnie $\mathrm{z}$ licencjami w strefie rozbudowy infrastruktury, turystyczno-rekreacyjnej działalności

i produkcji eksportowej (ryc. 1). 
Ryc. 1. Punkty specjalnej strefy ekonomicznej „Jaworiw”

Legenda: 1. międzynarodowe samochodowe przejście graniczne oraz kompleks serwisowo-rekreacyjny „Krako-wiec”, 2. przedsiębiorstwo górniczo-chemiczne „Siarka” („Sirka”), 3. obiekty przemysłu miasta Nowojaworowska oraz gminy Szkło, 4. park narodowy (strefa chroniona) „Roztoczczia”,

5. projektowana ówcześnie trasa samochodowa szybkościowa

Specjalny tryb funkcjonowania strefy polegać będzie na ulgach podatkowych i kredytowych. Odpowiednie licencje na działalność wydawać będzie konsorcjum „Jaworiw”, które powstało w formie otwartej spółki akcyjnej. Konsorcjum liczy na włączenie się w działalność w strefie następujących kapitałów:

- kapitał ukraińskich firm prywatnych - 40\%;

- środki organizacji i przedsiębiorstw państwowych krajowych - 30\%;

- kapitał organizacji międzynarodowych - 15\%;

- kapitał firm zagranicznych - $15 \%$.

Działalność podmiotów w SSE organizuje się w ramach projektów, wśród których najważniejszym projektem jest 16 przedsiębiorstw przemysłowych. Największe wśród nich jest przedsiębiorstwo „Siarka” („Sirka”), które obecnie wykorzystuje tylko 27\% swojego potencjału wydobywczego. Projekt decyduje o wprowadzeniu nowych schematów i technologii wytwarzania siarki z obniżeniem własnych kosztów produkcji, przeprofilowaniu przedsiębiorstwa polegającego na wprowadzeniu nowych wyrobów, rekultywacji ziemi z odnowieniem systemu wodnego i warunków ekologicznych. W strefie punktowej zamierza się realizować projekty wytwarzania energii elektrycznej, siarkobetonu, oliw technicznych i in. Zdecydowano także o budowie zachodnioukraińskiej rafinerii ropy naftowej.

W sferze infrastruktury zaplanowano budowę międzypaństwowego przejścia granicznego dla samochodów Krakiweć-Korczowa, budowę strefy obsługi serwisowej „Autoport Krakiweć", budowę magistrali międzynarodowej Kraków-Lwów i budowę obiektów infrastruktury usługowej.

Otwarcie przejścia granicznego Krakiwiec-Korczowa skróci drogę Kraków-Lwów o $26 \mathrm{~km}$. Zakłada się, iż stworzenie drugiej, roztoczańskiej strefy rekreacyjnej dla ok. 150 tys. osób może przynieść dochód 5-12 mln dol. rocznie. W wyniku tych działań w pierwszych 5 latach bezrobocie powinno się zmniejszyć do 6-8\%. Działalność strefy umożliwi wypracowanie nowych instrumentów dla państwowej polityki celnej i podatkowej, stworzenie systemu usług bankowych oraz inne możliwości w polityce regionalnej.

\section{Literatura}

Prawo Ukrainy „O zasadach ogólnych stworzenia i działalności specjalnych (swobodnych) stref ekonomicznych”. Postanowa Rady Werchownej Ukrainy od 13.II.1992. Kijów. \{Закон України „Про загальні засади створення і функціонування спеціальних (вільних) економічних зон”. Постанова Верховної Ради України від 13.II.1992. Київ.\}

„Koncepcja stworzenia specjalnych swobodnych stref ekonomicznych na Ukrainie”. Dodatek do postanowy Kabinetu Ministryw Ukrainy od 14 marca 1994 roku. Numer 164. \{Концепція 
створення спеціальних вільних економічних зон в Україні. Додаток до постанови Кабінету Міністрів України від 14 березня 1994 року. №164.\} 